\title{
KAWASAN HIJAU ORGANIK BERBASIS PERTANIAN BERLANJUT DESA PENGALANGAN, KECAMATAN MENGANTI, KABUPATEN GRESIK
}

\author{
Dwiyana Anela Kurniasari \\ Universitas Wijaya Putra \\ dwiyanaanela@uwp.ac.id
}

\begin{abstract}
Abstrak
Tujuan dari kegiatan pemberdayaan ini adalah (1) Meningkatkan kemampuan masyarakat dalam pemanfaatan lahan pekarangan untuk budidaya tanaman sayuran organik berbasis pertanian berlanjut, (2) Meningkatkan kemampuan masyarakat dalam mengelola hasil pasca panen dari lahan pekarangan. Metode pemberdayaan yang digunakan adalah community development dengan cara melibatkan masyarakat secara langsung dalam kegiatan pemberdayaan serta didukung dengan metode edukasi dengan cara memberikan pelatihan keterampilan budidaya sayuran dan pengolahan hasil pasca panen sayuran tersebut. Pelaksanaan program ini dibagi menjadi tiga tahapan yaitu perencanaan, pelaksanaan dan evaluasi. Hasil dari kegiatan pemberdayaan ini adalah rata-rata panen pertama bayam hijau adalah sebesar 455,18 gram. Komoditas bayam merah mampu menghasilkan panen rata-rata 380,43 gram pada panen pertama. Komoditas sawi pada panen pertama rata-rata 700,08 gram. Sedangkan untuk komoditas kangkung sebesar 435,53 gram. Hal tersebut mampu menurunkan kebutuhan belanja sayur warga peserta program dengan rata-rata sebelum program sebesar Rp. 14.152,-/per hari menjadi Rp. 10.562,-/hari dengan selisih rata-rata Rp. 3.010,00 atau mengalami penurunan rata-rata sebesar 21,37\%. Ibu rumah tangga binaan di Desa Pengalangan terbantu dengan pemanfaatan lahan pekarangan, sehingga mereka mampu mencukupi kebutuhan sayur keluarga.
\end{abstract}

Kata Kunci : pertanian organik, pertanian berlanjut, pemanfaatan pekarangan

\section{PENDAHULUAN}

Indonesia merupakan salah satu negara berkembang dengan jumlah peningkatan penduduk yang tinggi. Pada tahun 2018 jumlah penduduk Indonesia sebesar 265 juta jiwa dan pada tahun 2019 jumlah penduduk Indonesia mencapai 267 juta jiwa (Badan Pusat Statistik, 2019). Terjadi kenaikan jumlah penduduk dari tahun 2018 hingga 2019 sebesar 2 juta jiwa. Kecenderungan pertumbuhan jumlah penduduk diikuti langsung dengan peningkatan kebutuhan pangan. Negara dengan penduduk padat dituntut untuk mampu mengatasi permasalahan kebutuhan pangan rakyatnya. ( Xiaoqiang1, et al., 2019)

Pada saat ini ketersediaan lahan sawah pertanian di Indonesia mengalami penurunan yaitu pada tahun 2017 sebesar 7,75 juta hektar dan pada tahun 2018 sebesar 7,1 juta hektar (Badan Pusat statistik, 2018). Terjadi penurunan antara tahun 2017 ke 2018 adalah sebesar 0,65 juta hektar. Padahal semakin tahun penduduk di Indonesia juga semakin bertambah, namun lahan pertanian semakin berkurang. Salah satu solusi untuk memecahkan masalah pengalih fungsian yang berdampak pada ketahanan pangan adalah dengan optimalisasi lahan 
pertanian yang berkelanjutan. (Erbaugh, Bierbaum, Castilleja, Fonseca, \& Hansen, 2019)

Prediksi global dan efek perubahan iklim telah muncul dalam beberapa tahun terakhir sehingga ketersediaan kebutuhan pangan saat ini dipengaruhi tidak dapat mengandalkan hasil panen saja. Pemanfaatan lahan pekarangan di rumah-rumah tradisonal Suku Aborigin mampu mencapai keseimbangan pangan rumah tangga (O;Rourke \& Nash, 2019). Sehingga optimalisasi lahan pekarangan dengan melakukan budidaya tanaman pangan diharapkan mampu membantu ketahanan pangan rumah tangga.

Lahan pekarangan di Indonesia pada umunya belum dimanfaatkan secara maksimal. Luas lahan pekarangan di Indonesia adalah sebesar 10,3 juta hektar atau $14 \%$ luas pekarangan nasional belum dimanfaatkan dari seluruh lahan pertanian. (Badan Pusat Statistik, 2015). Saat ini pemerintah melalui Kementerian Pertanian mulai menggalakkan pemanfaatan lahan pekarangan sebagai salah bentuk untuk meningkatkan ketahanan pangan keluarga (Bantacut, 2013). Paling tidak dengan optimalisasi lahan pekarangan dengan cara melakukan budidaya tanaman pangan mampu menurunkan biaya belanja pangan di tingkat rumah tangga.

Kabupaten Gresik merupakan salah satu kabupaten di Jawa Timur dengan luas lahan pertanian sebesar 38.053 hektar dengan julmlah penduduk sebesar 1.177 juta penduduk (Badan Pusat Statistik Jatim, 2017). Sehingga dibutuhkan upaya untuk memenuhi ketersediaan pangan bagi masyarakat Kabupaten Gresik. Salah satu daerah di Kabupaten Gresik yang memproduksi komoditas tanaman pangan adalah Desa Pengalangan Kecamatan Menganti. Desa Pengalangan menanam komoditas pangan seperti padi, jagung, cabai, kangkung, sawi, tomat dan selada.

Jumlah petani di Desa Pengalangan adalah sebesar 1.621 jiwa dari total seluruh masyarakatnya sebesar 5.404 jiwa. Sehingga sebagian besar pekerjaan masyarakat Desa Pengalangan adalah petani. Namun jika terjadi masa kemarau mereka cukup sulit untuk melakukan penanaman komoditas sayuran. Hal tersebut berdampak pula pada ketersediaan sayur pada tingkat rumah tangga.

Hasil observasi lapang yang telah dilakukan peneliti, lahan pekarangan masyarakat Desa Pengalangan tidak dimanfaatlkan dengan baik. Hal tersebut dapat dilihat dari lahan pekarangan masyarakat yang kosong tidak manfaatkan. Padahal dengan optimalisasi lahan pekarangan untuk dimanfaatkan sebagai budidaya sayur dapat membantu meningkatkan kecukupan pangan keluarga, dan juga dapat membantu perekonomian keluarga.

Optimalisasi lahan pekarangan meruapakan salah satu solusi bagai pertanian di lahan yang sempit. Pemanfaatan lahan pekarangan dengan budidaya tanaman sayuran dapat dilakukan dengan menerapkan sistem pertanian berlanjut. Penerapan sistem pertanian berlanjut ini dapat memberikan dampak positif bagi keberlanjutan ekonomi, sosial dan lingkungan. (Gideon, Amponsah, Charles, Stephen, \& Imoro, 2019). Sistem pertanian berlanjut ini terdiri dari dengan mengutamakan sumber daya lokal disertai dengan pemanfaatan pengetahuan lokal (local wisdom) sehingga kelestarian alam pun tetap terjaga.

Potensi ibu rumah tangga di Desa Pengalangan ini besar, karena hanya suami yang bekerja di lahan sedangkan para istri mengurus anak dan rumah saja. Dari hasil observasi lapang, ibu rumah tangga di Desa Pengalangan kurang terampil dalam mengolah sayuran yang dapat dijual atau bernilai tambah. Mereka membutuhkan pendampingan dalam pemanfaatan lahan pekarangan untuk budidaya tanaman sayuran dan pelatihan keterampilan mengolah produk sayuran dengan nilai tambah.

Berdasarkan pemasalahan di atas dirumuskan tujuan dari pemberdayaan ini adalah (1) Meningkatkan kemampuan masyarakat dalam pemanfaatan lahan pekarangan untuk budidaya tanaman sayuran organik berbasis pertanian berlanjut, (2) Meningkatkan kemampuan masyarakat dalam mengelola hasil pasca panen dari lahan pekarangan.

\section{METODE}

Metode pendekatan yang digunakan dalam kegiatan pemberdayaan ini adalah Community Development. Community Development merupakan pendekatan yang berorientasi kepada upaya-upaya pengembangan pemberdayaan kepada masyarakat dengan menjadikan masyarakat sebagai subjek

$$
\text { Pangan dan Kesehatan }
$$

538 
sekaligus objek pembangunan dan melibatkan masyarakat secara langsung dalam berbagai kegiatan pemberdayaan. Hal tersebut sebagai upaya meningkatkan peran serta mereka dalam pembangunan demi kepentingan mereka sendiri. Selain itu metode pendekatan yang digunakan adalah metode edukasi dengan cara memberikan pelatihan kepada masyarakat berupa pelatihan budidaya keterampilan pengolahan makanan.

Sasaran dari Program Kawasan Hijau Organik berbasis Pertanian Berlanjut adalah ibu-ibu rumah tangga di Dusun Pengalangan, Desa Pengalangan, Kecamatan Menganti, Kabupaten Gresik. Jumlah peserta program ini adalah $105 \mathrm{ibu}$ rumah tangga.

Pelaksanaan program pemberdayaan ini dibagi menjadi 3 tahap yaitu perencanaan, pelaksanakan dan evaluasi. Kegiatan yang dilakukan pada tahan perencanaan adalah (1) Perumusan program berdasarkan hasil observasi permasalahan di Desa Pengalangan yaitu pemanfaatan lahan pekarangan tidak maksimal dan rendahnya keterampilan ibu-ibu dalam mengolah sayuran yang bernilai tambah. (2) Melakukan sosialisasi program kepada Ibu-ibu Desa Pengalangan.

Melaksanakan diskusi mengenai jenis tanaman yang akan ditanam sesuai dengan kebutuhan Ibu-ibu Desa Pengalangan.

Pada tahap pelaksanaan dilakukan metode edukasi yang berupa pelatihan dan praktik; (1) Melaksanakan pelatihan budidaya tanaman sayuran organik di polybag dengan sistem pertanian berlanjut. (2) Melakukan budidaya sayuran dengan sistem pertanian organik, pemeliharaan hingga pemanenan. (3) Pelatihan pembuatan olahan sayuran dan pengemasan (4) Demo dan lomba memasak olahan sayuran bernilai tambah.

Pada tahap evaluasi yang dilaksanakan adalah (1) Penilian hasil panen pelaksanaan budidaya sayuran dengan sistem organik. (2) Penilian tingkat efisiensi belanja sayuran per hari di tingkat rumah tangga.

\section{HASIL DAN PEMBAHASAN}

\section{Deskripsi Lokasi}

Kegiatan program Kawasan hijau Organik Berbasis Pertanian Berlanjut ini dilaksanakan di
Dusun Pengalangan, Desa Pengalangan, Kecamatan Menganti, Kabupaten Gresik. Desa Menganti ini terletak 6,4 km dari Ibu Kota Kecamatan Menganti, $23 \mathrm{~km}$ dari Ibu Kota Kabupaten Gresik, dan 18 km dari Ibu Kota Provinsi Jawa Timur. Akses dari desa pengalangan menuju ibu kota kecamatan, kabupaten dan provinsi menunjukkan bahwa jaraknya dekat sehingga mempermudah dan memperlancar keluar masuknya pengetahuan dan teknologi.

Desa Pengalangan terdiri dari 4 Dusun yaitu Dusun Pengalangan, Dusun Bongso Wetan, Dusun Bongso Kulon dan Dusun Songgot. Masyarakat Desa Pengalangan beragama Islam dan Hindu, sehingga di desa terdapat Pura sebagai tempat ibadah masyarakat agama Hindu. Pada hari raya Agama Hindu banyak masyarakat dari daedrah lain untuk datang melakukan kegiatan upacara keagamaan.

Pekerjaan utama masyarakat Desa Pengalangan adalah petani. Petani di lokasi pemberdayaan ini melaksanakan usahatani setiap waktu, tidak hanya pada musim penghujan saja tapi juga pada musim kemarau. Komoditas pertanian yang ditanam di Desa Pengalangan adalah cabai, tomat, sawi, bayam, kangkung dan jagung. Komoditas unggulan di Desa Pengalangan adalah cabe.

Jenis pemukiman masyarakat Desa pengalangan adalah memanjang, yang artinya pemukiman berada di sepanjang pinggir kanan dan kiri memanjang mengikuti jalan desa, sedangkan lahan mereka berada jauh dari rumah. Seluruh pemukiman masyarakat di Desa Pengalangan memiliki pekarangan rumah di bagian depan. Namun pekarangan rumah masyarakat Desa Pengalangan tidak dimanfaatkan dengan maksimal. Padahal sebesar 1.621 jiwa bekerja sebagai petani dari total seluruh masyarakatnya sebesar 5.404 jiwa.

Laki-laki di Desa Pengalangan bekerja sebagai petani, sedangkan istri mereka tidak bekerja atau sebagai ibu rumah tangga. Kegiatan ibu rumah tangga masyarakat Desa Pengalangan adalah mengurus rumah dan mengantarkan anak sekolah. Setelah itu sebagian besar ibu-ibu menganggur tidak melakukan kegiatan, sehingga program Kawasan Hijau Organik Berbasis pertanian Berlanjut mampu membantu ibu-ibu rumah tangga di Desa Pengalangan untuk berbudidaya tanaman sayuran organik dengan optimalisasi pemanfaatan pekarangan rumahnya.

$$
\text { Pangan dan Kesehatan }
$$




\section{Optimalisasi Lahan Pekarangan Melalui Program Kawasan Hijau Organik Berbasi Pertanian Berlanjut}

\section{Optimalisasi pemanfaatan pekarangan} dilakukan melalui upaya pemberdayaan wanita untuk mengoptimalkan manfaat pekarangan sebagai sumber pangan keluarga. Upaya ini dilakukan dengan membudidayakan berbagai jenis tanaman sayur yang telah disepakati bersama masyarakat Desa Pengalangan adalah bayam hijau, bayam merah, sawi dan kangkung yang mengandung vitamin dan mineral. Dengan demikian akan dapat terbentuk sebuah kawasan yang kaya akan sumber pangan yang diproduksi sendiri dalam kawasan tersebut dari optimalisasi pekarangan.

Pendekatan pengembangan ini dilakukan dengan mengembangkan pertanian berkelanjutan (sustainable agriculture), antara lain dengan mengutamakan sumber daya lokal disertai dengan pemanfaatan pengetahuan lokal (local wisdom) sehingga kelestarian alam pun tetap terjaga. Implementasi kegiatan ini disebut Kawasan Hijau Organik Berbasis Pertanian Berlanjut

Upaya untuk membantu terciptanya lingkungan hidup yang sehat dan membantu meningkatkan pendapatan rumah tangga dimulai dari peran serta wanita, khususnya ibu rumah tangga dalam meningkatkan nilai tambah dari lahan pekarangan. Pengelolaan pekarangan menjadi berbagai jenis tanaman sayuran skala rumah tangga atau dalam polibag menjadi suatu alternatif yang menjanjikan.

Sebagai fasilitator harus menyebarluaskan pengetahuan tentang cara-cara diversifikasi produksi pangan dan sayuran yang di waktu waktu mendatang makin penting, mengingat kualitas maupun kuantitas sayuran makin beragam dan ada kecenderungan makin tinggi persaingannya.

Pada kegiatan program Kawasan Hijau Organik Berbasis Pertanian Berlanjut ini dibagi menjadi 3 tahapan yaitu persiapan, pelaksanaan dan evaluasi. Pada tahap persiapan ini dilakukan sosialisasi program kepada Ibu-ibu Desa Pengalangan tentang pentingnya optimalisasi lahan pekarangan. Selanjutnya dilaksanakan diskusi mengenai jenis tanaman yang akan ditanam sesuai dengan kebutuhan Ibu-ibu Desa Pengalangan. Sesuai dengan kesepakatan bahwa tanaman yang akan dibudidayakan adalah bayam hijau, bayam merah, sawi dan kangkung.

Pada tahap pelaksanaan program Kawasan Hijau Organik Berbasis Pertanian Berlanjut ini, Ibuibu Desa Pengalangan diberikan pelatihan budidaya tanaman sayuran organik di polybag dengan sistem pertanian berlanjut. Sistem pertanian berlanjut ini memanfaatkan sumber daya lokal dengan menggunakan bibit yang berasal dari para petani Desa Pengalangan. Selain itu digunakan sistem budidaya pertanian organik supaya tetap mejaga kelestarian alam dan kesehatan warga. Pupuk yang digunakan untuk budidaya adalah pupuk cair organik produksi Fakultas Pertanian Universitas Wijaya Putra. Pemanfaatan pengetahuan lokal (local wisdom) dengan cara pendampingan budidaya tanaman sayur yang dilakukan dengan mengajak petani Desa Pengalangan sebagai fasilitator.

Kegiatan selanjutnya adalah praktik budidaya sayuran dengan sistem pertanian organik, pemeliharaan hingga pemanenan yang dilakukan oleh peserta program dengan pendampingan dari fasilitator selama masa tanam sayuran tersebut selama 1 (satu) bulan. Kegiatan selanjutnya adalah pelatihan pembuatan olahan sayuran dan pengemasan. Kegiatan ini dilakukan dengan memanfaatkan pertemuan PKK Desa Pengalangan dengan diselingi dengan pelatihan pembuatan olahan sayur bayem. Selain itu diberikan juga pelatihan pengemasan produk yang sesuai untuk dijual di pasar.

Kegiatan pelatihan pembuatan olahan sayur bayem ini juga ditunjang dengan demo pembuatan olahan sayur bayam difasilitasi oleh chef dari PT Wilmar yang berpengalaman. Setelah dilakukan demo memasak, dilakukan lomba memasak olahan sayur bayam yang bernilai tambah. Lomba diikuti oleh 10 kelompok yang terdiri dari perwakilanperwakilan RT Desa Pengalangan.

Pada tahap evaluasi yang pertama dilaksanakan dengan melakukan penilian hasil panen pertama pelaksanaan budidaya sayuran organik. Hasil panen pertama budidaya sayuran bayam hijau, bayam merah, sawi dan kangkung terdapat di Tabel 1 pada Lampiran 1. Rata-rata hasil panen pertama 
budidaya sayur bayam hijau yang diikuti oleh 105 peserta adala sebesar 455,18 gram. Hasil panen pertama budidaya sayur bayam merah dengan ratarata sebesar 380,43 gram. Rata-rata hasil panen pertama budidaya sayur sawi adalah sebesar 700,08 gram. Sedangkan hasil panen pertama budidaya kangkung memiliki rata-rata sebesar 435,53 gram. Dari Tabel 1 di Lampiran 1 menunjukkan hasil panen antar peserta program berbeda-beda. Hal tersebut dikarenakan perawatan yang dilakukan antar peserta program tidak sama atau tidak sesuai dengan anjuran fasilitator. Peserta terkadang lupa untuk melakukan penyiraman rutin atau waktu pemupukan yang telat. Selain itu peletakan polybag yang tidak mendapatkan sinar matahari cukup dan gangguan dari hewan disekitar rumah peserta seperti ayam, tikus dan kucin membuat beberapa batan tanaman sayur mengalami kerusakan.

Tahap evaluasi kedua adalah penilian tingkat efisiensi belanja sayuran per hari di tingkat rumah tangga. Berdasarkan Tabel 2 di Lampiran 2 menunjukkan bahwa rata-rata belanja 105 peserta program per hari adalah Rp. 14.152,00. Namun setelah adanya Program Kawasan Hijau Organik Berbasis Pertanian Berlanjut dalam Tabel 2 Lampiran 2 menunjukkan bahwa rata-rata belanja per hari sebesar $\mathrm{Rp} 11.142,00$. Hal tersebut menunjukkan bahwa terjadi penurunan rata-rata biaya belanja peserta sebesar Rp 3.010,00 atau $21,37 \%$. Dari informasi tersebut dapat disebutkan bahwa dengan adanya kegiatan program Kawasan Hijau Organik Berbasis Pertanian Berlanjut mampu memberikan dampak kepada peserta program dengan menurunkan biaya belanja harian sebesar $21,37 \%$.

\section{KESIMPULAN}

Pada seluruh rangkaian kegiatan program Kawasan Hijau Organik Berbasis Pertanian Berlanjut dapat disimpulkan bahwa: (1) Hasil panen pertama budidaya bayam hijau sebesar 455,18 gram, bayam merah dengan rata-rata sebesar 380,43 gram, budidaya sayur sawi adalah sebesar 700,08 gram dan budidaya kangkung memiliki rata-rata sebesar 435,53 gram. Hasil panen antar peserta program berbeda-beda. Hal tersebut dikarenakan perawatan yang dilakukan antar peserta program tidak sama atau tidak sesuai dengan anjuran fasilitator dan adanya hewan disekitar rumah peserta yang merusak tanaman tersebut. (2) Program Kawasan Hijau Organik Berbasis Pertanian Berlanjut mampu memberikan dampak bagi peserta program dengan menurunkan biaya belanja sayur harian dengan ratarata sebesar $21,37 \%$. (3) Ibu rumah tangga Desa Pengalangan mendapatkan pengetahuan dan keterampilan dalam mengolah sayur bayam bernilai tambah.

\section{UCAPAN TERIMA KASIH}

Terima kasih kepada Universitas Wijaya Putra telah memberikan kontribusi dalam bentuk bantuan finansial dan bimbingan sehingga kegiatan Pengabdian Kepada Masyarakat ini dapat dilaksanakan dengan baik.

\section{REFERENSI}

Badan Pusat Statistik. (2015). Luas Lahan Menurut Penggunaan. Jakarta: Badan Pusat Statistik.

Badan Pusat statistik. (2018). Hasil Survei Pertanian Antar Sensus 2018. Jakarta: Badan Pusat statistik.

Badan Pusat Statistik. (2019). Statistik Indonesia 2019. Jakarta: Badan Pusat Statistik.

Badan Pusat Statistik Jatim. (2017). Hasil Sensus Pertanian Jawa Timur. Surabaya: Badan Pusat Statistik Jatim.

Bantacut, T. (2013). Pembangunan Ketahanan Ekonomi dan Pangan Perdesaan Mandiri Berbasi Nilai Tambah. PANGAN, 397-406.

Erbaugh, J., Bierbaum, R., Castilleja, G., Fonseca, G., \& Hansen, S. (2019). Toward sustainable agriculture in the tropics. World Development.

Gideon, A. A., Amponsah, G., Charles, P., Stephen, A. T., \& Imoro, B. (2019). A review of the role of urban agriculture in the sustainable city discourse. Cities, 104-119.

O;Rourke, T., \& Nash, D. (2019). Aboriginal yards in remote Australia: Adapting landscapes for indigenous. Landscape and Urban Planning, 124-132.

Xiao-qiang1, J., Hong-yan, Z., Wen-qi, M., Chong, W., Xiao-lin, L., \& Fu-suo, Z. (2019).

$$
\text { Pangan dan Kesehatan } \quad 541
$$


Science and Technology Backyard: A novel approach to empower smallholder farmers for sustainable intensification of agriculture in China. Journal of integrative Agriculture, 1657-1666.

\section{LAMPIRAN 1}

Tabel. 1 Rata-rata hasil panen pertama bayam hijau, bayam merah, sawi dan kangkung.

\begin{tabular}{|c|c|c|c|c|c|c|c|c|c|}
\hline $\begin{array}{c}\text { Sa. } \\
\text { Peata }\end{array}$ & Hail & $\begin{array}{l}\text { Hani } \\
\text { panen }\end{array}$ & & & 39 & 437 & 401 & $6 e ?$ & 390 \\
\hline Paerta & panen & bayam & panen & panca & 40 & 525 & 396 & 722 & 450 \\
\hline & $(g r a=)$ & $\begin{array}{l}\text { merah } \\
\text { (gram) }\end{array}$ & (gram) & (gram) & 41 & 391 & 375 & 718 & 410 \\
\hline 1 & 500 & 340 & 670 & 480 & 42 & 499 & 440 & 650 & 390 \\
\hline 2 & 480 & 420 & 681 & 450 & 43 & 467 & 377 & 697 & 450 \\
\hline 3 & 300 & 382 & 750 & 488 & 4 & 300 & 340 & 718 & 459 \\
\hline 4 & 490 & 361 & 668 & 395 & 45 & 450 & 420 & 630 & 390 \\
\hline 5 & 525 & 155 & & 480 & 46 & 510 & 382 & 654 & 462 \\
\hline 6 & 391 & 380 & 692 & $46 ?$ & 47 & $3(x)$ & 430 & 698 & 450 \\
\hline 7 & 499 & 402 & 778 & 480 & 48 & 502 & 381 & 730 & 476 \\
\hline 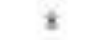 & 467 & 372 & 651 & 480 & (3) & 488 & 348 & 750 & 461 \\
\hline 4 & 512 & 381 & 721 & 479 & 50 & 450 & 387 & 668 & 420 \\
\hline 10 & 508 & 400 & 628 & 459 & 51 & 390 & 431 & 730 & 478 \\
\hline II & 476 & 352 & 7oo & 380 & $\$ 2$ & $4 \times$ & 389 & 692 & 380 \\
\hline 32 & $4 \times 2$ & 378 & 698 & 471 & 53 & 390 & 381 & 778 & 471 \\
\hline 13 & 524 & 360 & Tos & 355 & $\$ 4$ & 437 & 400 & 681 & 355 \\
\hline 14 & $4 T y$ & 388 & 631 & 443 & $\$ 5$ & 525 & 352 & 788 & +43 \\
\hline 15 & $4 D 0$ & 401 & 657 & 410 & 56 & 391 & $37 \mathrm{~K}$ & 650 & 410 \\
\hline 16 & 502 & 396 & 722 & 390 & 57 & 437 & 360 & 631 & 390 \\
\hline 17 & 488 & 375 & 710 & 450 & $\$ 8$ & 525 & $38 \mathrm{~K}$ & 783 & 450 \\
\hline 18 & 490 & 363 & $\cos \theta$ & 459 & 9) & 391 & 400 & 689 & 450 \\
\hline 19 & 300 & 37 & 697 & 390 & (a) & 499 & 352 & 705 & 488 \\
\hline 10 & 437 & 345 & 718 & 462 & 61 & 467 & 378 & 631 & 395 \\
\hline 21 & 525 & 358 & 688 & 450 & 62 & 512 & 360 & 657 & 480 \\
\hline 22 & 391 & 400 & 654 & 476 & 63 & 300 & 388 & 722 & 467 \\
\hline 27 & 499 & 377 & 650 & 380 & 64 & 490 & 401 & 705 & 480 \\
\hline 24 & 467 & 368 & 730 & 300 & 65 & 510 & 396 & 631 & 480 \\
\hline 15 & 512 & 331 & 742 & 410 & 66 & 36 & 375 & 657 & 450 \\
\hline 26 & sos & 390 & 688 & 487 & b) & 465 & 363 & 722 & 476 \\
\hline 27 & 398 & 326 & 726 & 390 & tos & 525 & 420 & $7 \pm 0$ & 380 \\
\hline $2 x$ & 400 & 366 & 687 & 461 & +20 & 391 & 382 & 680 & 300 \\
\hline 29 & 300 & 348 & 650 & 420 & Tu & 499 & 361 & 697 & 410 \\
\hline 30 & 350 & 387 & 742 & $47 \mathrm{~K}$ & 71 & 467 & 355 & 718 & 487 \\
\hline 31 & 410 & 431 & 783 & 430 & 72 & 512 & $34 \mathrm{~K}$ & 6211 & 390 \\
\hline 32 & 560 & 380 & 659 & 481 & 73 & 500 & 387 & .750 & 461 \\
\hline 33 & 410 & 381 & Tos & 459 & 74 & 525 & 431 & 668 & 420 \\
\hline 34 & 490 & 400 & 631 & 380 & 35 & 391 & 375 & 730 & 300 \\
\hline 35 & $\sin$ & 352 & 6.57 & 471 & 76 & 499 & 363 & 602 & 450 \\
\hline 36 & 488 & 378 & 722 & 355 & 77 & 467 & 371 & 738 & 459 \\
\hline 37 & $4 \times$ & 420 & 710 & 443 & To & $\$ 12$ & 340 & 681 & 390 \\
\hline 38 & 390 & 388 & $6 s 0$ & 410 & $\mathrm{~N}$ & 508 & 420 & 721 & 462 \\
\hline
\end{tabular}




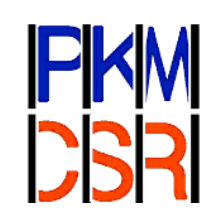

Prosiding PKM-CSR, Vol. 2 (2019)

e-ISSN : 2655-3570

\begin{tabular}{|c|c|c|c|c|}
\hline $\mathrm{BI}$ & $5(\theta)$ & 361 & 722 & 476 \\
\hline 82 & 410 & 355 & 78 & 380 \\
\hline 83 & $4 \times 3$ & 387 & 690 & 462 \\
\hline 84 & 502 & 431 & ES? & 450 \\
\hline $\mathrm{kS}$ & 48 & 389 & 718 & 476 \\
\hline 86 & 450 & 381 & 63 & 380 \\
\hline 87. & 300 & 400 & 654 & 300 \\
\hline 88 & 450 & 352 & 659 & 410 \\
\hline b) & 510 & $37 \mathrm{~K}$ & 730 & $4 \times 7$ \\
\hline$\omega$ & 350 & 360 & 750 & 300 \\
\hline 91 & 502 & 352 & 654 & 46] \\
\hline 92 & 48 & 378 & 6S9 & 300 \\
\hline 93 & $46)$ & 360 & 730 & 450 \\
\hline 94 & 390 & $38 \mathrm{~B}$ & 750 & 450 \\
\hline
\end{tabular}

\begin{tabular}{lrrrr}
\hline 95 & 490 & 461 & 668 & 488 \\
96 & 300 & 396 & 730 & 395 \\
97 & 391 & 375 & 657 & 480 \\
98 & 437 & 363 & 722 & 467 \\
90 & 525 & 389 & 710 & 490 \\
100 & 391 & 381 & 650 & 480 \\
101 & 499 & 400 & 697 & 450 \\
102 & 467 & 380 & 718 & 459 \\
103 & 512 & 378 & 732 & 399 \\
104 & 300 & 360 & 650 & 462 \\
105 & 450 & 440 & 654 & 450 \\
Rata-rata & 455,18 & 380,43 & 700,48 & 435.53 \\
\hline & & &
\end{tabular}




\section{LAMPIRAN 2}

Tabel. 2 Pengeluaran belanja sayur peserta program per hari.

\begin{tabular}{|c|c|c|}
\hline Na. Deacria & $\begin{array}{l}\text { Sebelum } \\
\text { Tregram }\end{array}$ & Sttelah Frogram \\
\hline 1 & 10.000 & 7.600 \\
\hline 2 & 14.000 & 10.500 \\
\hline 3 & 11.000 & 8.000 \\
\hline 4 & 13.000 & 9.500 \\
\hline 5 & 8.000 & 6.600 \\
\hline 6 & 16.000 & 7.500 \\
\hline 7 & 8.500 & 7.600 \\
\hline 8 & 10.50 & 7.500 \\
\hline 9 & 12.000 & 9000 \\
\hline 10 & 13.000 & 8.500 \\
\hline 11 & 11.500 & 8.000 \\
\hline 12 & 10.000 & 8.000 \\
\hline 13 & 12.000 & 9.500 \\
\hline 14 & 15.000 & 12.000 \\
\hline is & 10.000 & 8.000 \\
\hline 16 & 17.000 & 13,600 \\
\hline 17 & 25.000 & 20.000 \\
\hline 18 & 13.000 & 10.000 \\
\hline 19 & 14.000 & $\$ 1.000$ \\
\hline 20 & 10.500 & 8.600 \\
\hline 21 & 18.000 & 14500 \\
\hline 22 & 16.000 & 13.000 \\
\hline 23 & 17.500 & 14,000 \\
\hline 24 & 12000 & 9.600 \\
\hline 25 & 23.000 & 18.600 \\
\hline 26 & 22000 & 17.500 \\
\hline 27 & 18.500 & 13.500 \\
\hline 28 & Hiso & 8.500 \\
\hline 20 & 16.000 & 7.500 \\
\hline 30 & 12000 & 9600 \\
\hline 31 & 15.000 & 11.600 \\
\hline 32 & 10.000 & 7.500 \\
\hline 33 & 17.000 & 12.600 \\
\hline 34 & 25.000 & 18.500 \\
\hline 35 & 13.000 & 8.600 \\
\hline 36 & 11.000 & 8.500 \\
\hline 37 & 14.000 & 12.500 \\
\hline 38 & 5.000 & 6.500 \\
\hline 39 & 10.000 & 8.600 \\
\hline
\end{tabular}

\begin{tabular}{|c|c|}
\hline 5.500 & 7.300 \\
\hline $12 \mathrm{n}+00$ & 0.500 \\
\hline 23.000 & 18.600 \\
\hline 10.500 & 8.200 \\
\hline 18.500 & 14.000 \\
\hline 11.500 & 9.500 \\
\hline 10.000 & 8.600 \\
\hline 12.000 & $9 ., 000$ \\
\hline 15.000 & 12.000 \\
\hline 16.000 & 8.600 \\
\hline 17.000 & 13.600 \\
\hline 25.000 & 20.600 \\
\hline 17.000 & 13.500 \\
\hline 25000 & 20.600 \\
\hline 13.000 & 10.600 \\
\hline 11.000 & 8.500 \\
\hline 13.000 & 10.000 \\
\hline 18.500 & 14.500 \\
\hline 11.500 & 9.200 \\
\hline 16.000 & 8.600 \\
\hline 12.000 & 9,500 \\
\hline 15.000 & 12.000 \\
\hline 17.500 & 14.600 \\
\hline 12.000 & 9.500 \\
\hline 23.000 & 18.000 \\
\hline 16.000 & 8.600 \\
\hline 12.000 & 9,500 \\
\hline 15.000 & 12.000 \\
\hline 10.000 & 8.000 \\
\hline 17.000 & 13.500 \\
\hline 25.000 & 20.600 \\
\hline 17.000 & 1.3 .000 \\
\hline $12 . n 00$ & 9.500 \\
\hline 15.000 & 12.600 \\
\hline 10.000 & 8.600 \\
\hline 17.000 & 14.000 \\
\hline 25.800 & 20.600 \\
\hline 13.000 & 11.000 \\
\hline $1+.800$ & 12,000 \\
\hline 10500 & 8.600 \\
\hline 13.860 & 12.000 \\
\hline 18. 500 & 15,000 \\
\hline
\end{tabular}




\begin{tabular}{|c|c|c|}
\hline 82 & 11.500 & 10.000 \\
\hline 83 & 10000 & 8.000 \\
\hline 84 & 12000 & 8,600 \\
\hline 85 & 15.000 & 12.000 \\
\hline 86 & 17.500 & 14,000 \\
\hline 87 & 12000 & 9.500 \\
\hline 88 & 23.050 & 18,000 \\
\hline 89 & 10.000 & 8.600 \\
\hline 90 & 9.500 & 7,000 \\
\hline 91 & 12000 & 9.500 \\
\hline 92 & 23.000 & 18.400 \\
\hline 93 & 10.500 & 10.000 \\
\hline 94 & 18.500 & 26,000 \\
\hline 95 & 11.500 & 10.000 \\
\hline 96 & 18.500 & 56600 \\
\hline 97 & 11.500 & 10.000 \\
\hline 98 & 10.000 & 8.600 \\
\hline 99 & 12000 & 10.000 \\
\hline 100 & 15.000 & 12.600 \\
\hline 101 & 10.000 & 8.600 \\
\hline 102 & 12000 & 11.000 \\
\hline 10 & 15.000 & 12.600 \\
\hline 104 & 10.000 & 8.600 \\
\hline 105 & 17.000 & 14.600 \\
\hline Rata-rata & 14.152 & 11.142 \\
\hline
\end{tabular}

